\title{
Complement regulation in ovine lymph nodes during early pregnancy
}

\author{
LEYING ZHANG* ${ }^{*}$ LIDONG CAO* ${ }^{*}$ PENGFEI FENG, XU HAN and LING YANG \\ Department of Animal Science, School of Life Sciences and Food Engineering, Hebei University of Engineering, \\ Handan, Hebei 056038, P.R. China
}

Received July 8, 2021; Accepted December 8, 2021

DOI: $10.3892 /$ etm.2021.11089

\begin{abstract}
A fetus changes immune responses in the uterus and the maternal immune system, and lymph nodes are associated with regulating maternal adaptive immunity. Complement activation is associated with abnormal pregnancy in mice and humans. The aim of the present study was to explore the expression levels of complement components in maternal lymph nodes during early pregnancy in sheep. Maternal inguinal lymph nodes were sampled on day 16 of the estrous cycle, and days 13, 16 and 25 of gestation in ewes. Reverse transcription-quantitative PCR, western blotting and immunohistochemical analyses were used to detect the expression levels of complement components C1q, C1r, C1s, C2, C3, $\mathrm{C} 4 \mathrm{a}, \mathrm{C} 5 \mathrm{~b}$ and $\mathrm{C} 9$ in the lymph nodes. The results revealed that the protein and mRNA levels of $\mathrm{Clq}, \mathrm{C} 1 \mathrm{~s}$ and $\mathrm{C} 5 \mathrm{~b}$ were enhanced during early pregnancy, and that $\mathrm{C} 1 \mathrm{r}$ and $\mathrm{C} 4 \mathrm{a}$ were upregulated at day 25 of pregnancy. The mRNA and protein levels of C2 and C9 peaked at day 16 of pregnancy, but C3 was decreased at day 25 of pregnancy. C3 protein was located in the subcapsular sinuses and lymph sinuses of the maternal lymph node. In summary, the present study detected changes in the expression levels of complement components in maternal lymph nodes, which may be associated with maternal immune regulation during early pregnancy in sheep.
\end{abstract}

\section{Introduction}

During pregnancy, the fetus not only evades but also provokes immune responses in the uterus, maternal peripheral tissues and immune system, which are essential for the success of pregnancy (1). Lymph nodes are secondary lymphoid

Correspondence to: Professor Ling Yang, Department of Animal Science, School of Life Sciences and Food Engineering, Hebei University of Engineering, 19 Taiji Road, Handan, Hebei 056038, P.R. China

E-mail: yangling@hebeu.edu.cn

*Contributed equally

Key words: lymph node, pregnancy, complement component, sheep organs that participate in inducing and regulating adaptive immunity (2). Pregnancy induces an increase in the weights of lumbar, renal and inguinal lymph nodes in mice (3), and the weights of iliac lymph nodes also increase progressively during pregnancy in rats (4).

It has been reported that early pregnancy induces increases in the expression levels of progesterone (P4) receptor, P4-induced blocking factor (5), cyclooxygenase 1 (COX-1), COX-2, prostaglandin E synthase, Aldo-keto reductase family 1 member B1 (6), interleukin (IL)-5 and IL-10, but TNF- $\beta$ and IL- 2 are decreased in the maternal lymph nodes during early pregnancy in sheep (7). Furthermore, there are increases in the protein expression levels of melatonin receptor 1 , cluster of differentiation 4 , signal transducer and activator of transcription 1, 2',5'-oligoadenylate synthetase, myxovirus resistance protein $1, \mathrm{C}-\mathrm{X}-\mathrm{C}$ motif chemokine 10 and gonadotropin releasing hormone and its receptor in the maternal lymph nodes during early pregnancy in sheep (8-10). Early pregnancy induces changes in maternal lymph nodes, which may be associated with maternal immune tolerance to paternal alloantigens.

The complement system plays important roles in innate immune defense, which are associated with shaping adaptive immune responses (11). The major effector fragments of the complement system that are associated with the innate and adaptive immune systems include complement components $\mathrm{C} 1, \mathrm{C} 3, \mathrm{C} 5$ and $\mathrm{C} 9$, and the $\mathrm{C} 1$ complex (C1qC1r2s2), while $\mathrm{C} 2$ and $\mathrm{C} 4$ are implicated in $\mathrm{C} 3$ convertase formation (12).

Complement activation can promote inflammation and facilitate macrophage phagocytosis to placenta-derived particles and apoptotic cells, and the complement system also serves as a regulator of complex tolerance in healthy pregnancy (13). Complement components are located in placental tissue, and are associated with protecting the semiallogenic conceptus against the maternal immune system in humans (14). However, a complement-mediated immune attack against semiallogeneic fetal tissues can occur, which leads to adverse pregnancy outcomes in humans and animals (15). Early pregnancy regulates expression of complement components in the liver and thymus in the ovine $(16,17)$. At present, it is unclear whether the expression of complement components is changed in maternal lymph nodes during early pregnancy in sheep.

During early gestation in ruminants, the trophectoderm of the conceptus secretes interferon-tau (IFNT), which 
participates in the maternal recognition of pregnancy and prevents luteolysis (18). IFNT increases the expression of interferon stimulated genes (ISGs) in the corpus luteum (CL) in an endocrine manner (19), and enhances the expression of ISGs in immune organs, including bone marrow (20), the thymus $(21)$, the spleen $(22,23)$ and lymph nodes $(6,9)$ during early pregnancy in sheep.

It is hypothesized that early pregnancy affects the expression of complement components in ovine lymph nodes. The objective of the present study was to explore the expression of the complement components C1q, C1r, C1s, C2, C3, C4a, C5b and C9 in maternal lymph nodes, which may be helpful for understanding the immune regulation of maternal lymph nodes during early pregnancy in sheep.

\section{Materials and methods}

Animals and experimental design. A total of 24 small-tail Han ewes (Ovis aries) 18 months old and average weight of $41 \mathrm{~kg}$ were observed daily for estrus in the presence of vasectomized rams at a farm in Handan, China. The ewes were housed under a condition of average atmospheric pressure of 1,027 hectopascals, a $11 \mathrm{~h}$ light/13 h dark cycle, temperature of $3-18^{\circ} \mathrm{C}$ and free access to food and water. The ewes were randomly divided into four groups ( $n=6$ for each group), and at estrus (day 0 ), the animals were mated to either intact or vasectomized rams. The females were necropsied on days 13 , 16 and 25 of pregnancy, and day 16 of the estrous cycle as described previously (9). Euthanasia of the ewes was performed by an experienced person to cut both the carotid arteries and jugular veins to bleed out the animals after electrical stunning. The uterus was flushed, and pregnancy was confirmed by the presence of a normal conceptus in the uterine lumen flushing. Transverse pieces of the inguinal lymph nodes were collected immediately after slaughter and snap-frozen in liquid nitrogen $\left(-196^{\circ} \mathrm{C}\right)$ until subsequent mRNA and protein analyses. In addition, longitudinal cross sections of the lymph nodes were cut into pieces $\left(0.3 \mathrm{~cm}^{3}\right)$, and fixed with fresh $4 \%$ buffered paraformaldehyde for $12 \mathrm{~h}$ at room temperature for subsequent immunohistochemical analysis. The study protocol was reviewed and approved by the Hebei University of Engineering Animal Care and Use Committee (approval no. 2019-017), and humane animal care and handling procedures were followed throughout the experiment.

$R N A$ extraction and reverse transcription-quantitative $P C R$ assay. The samples (transverse pieces of the inguinal lymph nodes) were crushed in liquid nitrogen, and total RNA was isolated using TRNzol Universal Reagent (DP424; Tiangen Biotech Co., Ltd.) according to the manufacturer's recommendations. A FastQuant RT kit with gDNase (cat. no. KR106; Tiangen Biotech Co., Ltd.) was used to remove genomic DNA and synthesize cDNA according to the manufacturer's instructions. The specific primers (Table I) were designed based on the sequences in the NCBI database (http://www. ncbi.nlm.nih.gov/) for the ovine C1q, C1r, C1s, C2, C3, $\mathrm{C} 4 \mathrm{a}, \mathrm{C} 5 \mathrm{~b}$ and $\mathrm{C} 9$ genes, and were synthesized by Shanghai Sangon Biotech Co., Ltd. Primer matrix experiments were performed to determine the optimal primer concentrations. The amplification efficiencies of the primer sequences were evaluated before quantification, and were in an acceptable range (between 0.9 and 1.1). A CFX96 real-time PCR system (Bio-Rad Laboratories, Inc.) was used for quantitative PCR in a total volume of $20 \mu \mathrm{l}$ in triplicate using a SuperReal PreMix Plus kit (Tiangen Biotech Co., Ltd.). Cycling conditions of PCR included an initial denaturation at $95^{\circ} \mathrm{C}$ for $10 \mathrm{~min}$ followed by 40 cycles of denaturation $\left(95^{\circ} \mathrm{C}\right.$ for $\left.10 \mathrm{sec}\right)$, annealing $\left(60-62^{\circ} \mathrm{C}\right.$ for $\left.20 \mathrm{sec}\right)$ and extension $\left(72^{\circ} \mathrm{C}\right.$ for $\left.25 \mathrm{sec}\right)$ followed by one cycle of final extension $\left(72^{\circ} \mathrm{C}\right.$ for $\left.7 \mathrm{~min}\right)$. The annealing temperatures were $60^{\circ} \mathrm{C}$ for $C 1 q, C 1 s, C 2, C 3$ and $C 9$, or $62^{\circ} \mathrm{C}$ for $C 1 r, C 4 a$ and $C 5 b$. Mean threshold cycle values $(\mathrm{Cq})$ for the target genes and $\mathrm{CT}$ values for the reference gene $(G A P D H)$ of each sample were calculated from triplicate wells, and the relative transcript abundances for the target genes were calculated using the $2^{-\Delta \Delta \mathrm{Cq}}$ analysis method (24). Mean Cq values of estrous cycle of day 16 were used to normalize the relative levels of mRNA transcripts.

Western blotting. The samples (transverse pieces of the inguinal lymph nodes) were homogenized using RIPA lysis buffer (Tiangen Biotech Co., Ltd.) to isolate total protein, and a BCA protein assay kit (Tiangen Biotech Co., Ltd.) was used to determine the concentrations of the total proteins. Total protein samples $(10 \mu \mathrm{g} /$ lane $)$ were separated by $12 \%$ SDS-PAGE gel, and transferred electrophoretically to polyvinylidene fluoride membranes (MilliporeSigma). The membranes were blocked with $5 \%$ (w/v) skim milk powder at $4^{\circ} \mathrm{C}$ overnight, and then incubated with a mouse anti-C1q monoclonal antibody (cat. no. sc-53544), a mouse anti-C1r monoclonal antibody (cat. no. sc-514105), a mouse anti-C1s monoclonal antibody (cat. no. sc-365273), a mouse anti-C2 monoclonal antibody (cat. no. sc-373809), a mouse anti-C3 monoclonal antibody (cat. no. sc-28294), a mouse anti-C4a monoclonal antibody (cat. no. sc-271181), a mouse anti-C5b monoclonal antibody (cat. no. sc-398247) and a mouse anti-C9 monoclonal antibody (cat. no. sc-390000) (all 1:1,000; Santa Cruz Biotechnology, Inc.) at $4^{\circ} \mathrm{C}$ overnight. After washing, the membranes were incubated with horseradish peroxidase (HRP) conjugated anti-mouse secondary antibody at a 1:2,000 dilution (cat. no. BL001A; Biosharp Life Sciences). The blots were detected using a pro-light HRP chemiluminescence kit (Tiangen Biotech Co., Ltd.). Densitometric analysis of the relative intensities of the blots was performed using a Quantity One v452 (Bio-Rad Laboratories, Inc.), and normalized to a reference protein (GAPDH) using an anti-GAPDH antibody (1:1,000; cat. no. sc-47724; Santa Cruz Biotechnology, Inc.).

Immunohistochemical analysis. The paraffin-embedded sections (5- $\mu \mathrm{m}$ thick) were deparaffinized and rehydrated in a series of xylene and ethanol. Some sections (transverse sections of the inguinal lymph nodes) were stained by hematoxylin for $30 \mathrm{sec}$ and eosin for $20 \mathrm{sec}$ at room temperature before antigen retrieval and staining with antibodies. The sections were boiled in citrate solution for $12 \mathrm{~min}$ at $100^{\circ} \mathrm{C}$ for antigen retrieval, washed with phosphate-buffered saline and then treated with $3 \%$ hydrogen peroxide to remove endogenous peroxidase activity. Blocking non-specific binding site in the sections was performed using $5 \%$ goat serum for $1 \mathrm{~h}$ at room temperature, and then incubated with the mouse anti-C3 monoclonal antibody (cat. no. sc-28294; 
Table I. Primers used for reverse transcription-quantitative PCR.

\begin{tabular}{|c|c|c|c|c|}
\hline Gene & Primer & Sequence $\left(5^{\prime}-3^{\prime}\right)$ & Size, bp & Accession numbers \\
\hline \multirow[t]{2}{*}{$C l q A$} & Forward & CAGGAGAACGTGTACCAGAGCAAC & 122 & XM_012152629.2 \\
\hline & Reverse & CTCCGAGAGGACCTGATGGACAG & & \\
\hline \multirow[t]{2}{*}{$C l r$} & Forward & CCCAGACTACCGCCAGGAAGAG & 109 & XM_012175492.2 \\
\hline & Reverse & TGGGAGGCAGATTGGCAGGAG & & \\
\hline \multirow[t]{2}{*}{ Cls } & Forward & CCTGGCAAGTCTTCTTCTCGAACC & 130 & XM_004006917.4 \\
\hline & Reverse & ACCACTGAGGAGGACCCAACATAC & & \\
\hline \multirow[t]{2}{*}{$C 2$} & Forward & CCACCAATCCCATCCAGCAGAAG & 95 & XM_027958809.1 \\
\hline & Reverse & GGCGTCCAGGAGCAGGTAGAG & & \\
\hline \multirow[t]{2}{*}{ C3 } & Forward & CGCCACCAGCAGACTATAACGATC & 105 & XM_027969774.1 \\
\hline & Reverse & AGCAGCCTTGACCTCCACCTC & & \\
\hline \multirow[t]{2}{*}{$C 4 \alpha$} & Forward & TTCAGGACAGGTGGTGAGAGGATC & 167 & XM_027958803.1 \\
\hline & Reverse & GGAGGAGATGGAGGCGACAGAG & & \\
\hline \multirow[t]{2}{*}{$C 5$} & Forward & GCTACGCTGGTGTTACTCTGGATC & 157 & XM_004003966.3 \\
\hline & Reverse & GCAGACATGACCTCGCCTATAAGC & & \\
\hline \multirow[t]{2}{*}{ C9 } & Forward & GCCGCAACAGAGTGGTGGAAG & 138 & XM_004017026.3 \\
\hline & Reverse & TGCCATCCCTAACTCGGTCACAG & & \\
\hline \multirow[t]{2}{*}{ GAPDH } & Forward & GGGTCATCATCTCTGCACCT & 176 & NM_001190390.1 \\
\hline & Reverse & GGTCATAAGTCCCTCCACGA & & \\
\hline
\end{tabular}

Santa Cruz Biotechnology, Inc.) at a final dilution of 1:200 at $4^{\circ} \mathrm{C}$ overnight. The tissue sections were further treated with the secondary antibody (cat. no. BL001A; Biosharp Life Sciences) for $45 \mathrm{~min}$ at room temperature. For negative control sections, the primary antibody was replaced with antiserum-specific isotype at the same dilution. A DAB kit (Enhanced HRP-DAB Chromogenic kit; Tiangen Biotech Co., Ltd.) was used to detect the specific binding sites according to the manufacturer's instructions. Digital images (magnification, $\mathrm{x} 400$ ) were captured using a light microscope (Nikon Eclipse E800; Nikon Corporation) with a DP12 digital camera. The intensities of staining digital images were examined independently by four observers. The immunostaining intensities of the samples from different ewes ( $n=6$ for each group) were analyzed through the images in a blind manner. Staining intensities for $\mathrm{C} 3$ protein were calculated by assigning an immunoreactive intensity on a scale of 0 to 3 , as described previously (25). The staining intensity was as follows: $0=$ negative; $1+=$ weak; $2+=$ strong.

Statistical analysis. Statistical analysis was performed using least-squares ANOVA in mixed and general linear model procedures of the Statistical Analysis System v9.2 (SAS Institute, Inc.). Day and status (cyclic or pregnant), and interaction between day and status on expression of mRNA and protein were tested using repeated measure for multivariate analysis of variance. Numerical data were presented as least squares means with standard errors, and comparison of means was tested by Tukey HSD test. $\mathrm{P}<0.05$ was considered to indicate a statistically significant difference.

\section{Results}

Relative expression levels of C1q, C1r, C1s, C2,C3,C4a,C5b and $C 9 \mathrm{mRNA}$ in lymph nodes. The relative expression levels of $C l q, C l s$ and $C 5 b$ mRNA were significantly higher during pregnancy compared with day 16 of the estrous cycle $(\mathrm{P}<0.05)$, and the level of $C l q$ mRNA was the highest at day 16 of pregnancy among the four groups (Fig. 1). The relative expression levels of C1r and C4a mRNAs were increased at day 25 of pregnancy compared with those at day 16 of the estrous cycle, and at days 13 and 16 of pregnancy $(\mathrm{P}<0.05)$. The levels of $C 2$ and $C 9$ mRNAs were the highest at day 16 of pregnancy among the four groups $(\mathrm{P}<0.05)$. In addition, the $C 3 \mathrm{mRNA}$ level was the highest at day 16 of pregnancy, and was the lowest at day 25 of pregnancy among the four groups $(\mathrm{P}<0.05)$.

Expression levels of $C 1 q, C 1 r, C 1 s, C 2, C 3, C 4 a, C 5 b$ and C9 proteins in lymph nodes. Western blotting indicated that there was almost no expression of $\mathrm{C} 1 \mathrm{~s}$ protein on day 16 of the estrous cycle, but pregnancy induced the expression of C1q, C1s and C5b proteins in lymph nodes compared with day 16 of the estrous cycle $(\mathrm{P}<0.05$; Fig. 2$)$. In addition, the Clq protein level was the highest at day 16 of pregnancy, and the $\mathrm{C} 1 \mathrm{~s}$ protein level was the highest at day 13 of pregnancy among the four groups $(\mathrm{P}<0.05)$. There was very low expression of $\mathrm{C} 1 \mathrm{r}$ and $\mathrm{C} 4 \mathrm{a}$ proteins at day 16 of the estrous cycle, and days 13 and 16 of pregnancy, but the expression levels of $\mathrm{C} 1 \mathrm{r}$ and $\mathrm{C} 4 \mathrm{a}$ proteins were significantly upregulated at day 25 of pregnancy compared with the other three groups $(\mathrm{P}<0.05)$. C2 and $\mathrm{C} 9$ proteins were highly expressed at day 16 of pregnancy, but their expression levels were very low at day 16 of the estrous cycle, and days 13 and 25 of pregnancy. Furthermore, the C3 protein level at day 16 of pregnancy was the highest among the four groups, and was very low at day 25 of pregnancy $(\mathrm{P}<0.05)$.

Immunohistochemistry for C3 protein in the lymph nodes. The $\mathrm{C} 3$ protein was located in the subcapsular sinuses and lymph sinuses, but there was almost no immunostaining in lymphoid 

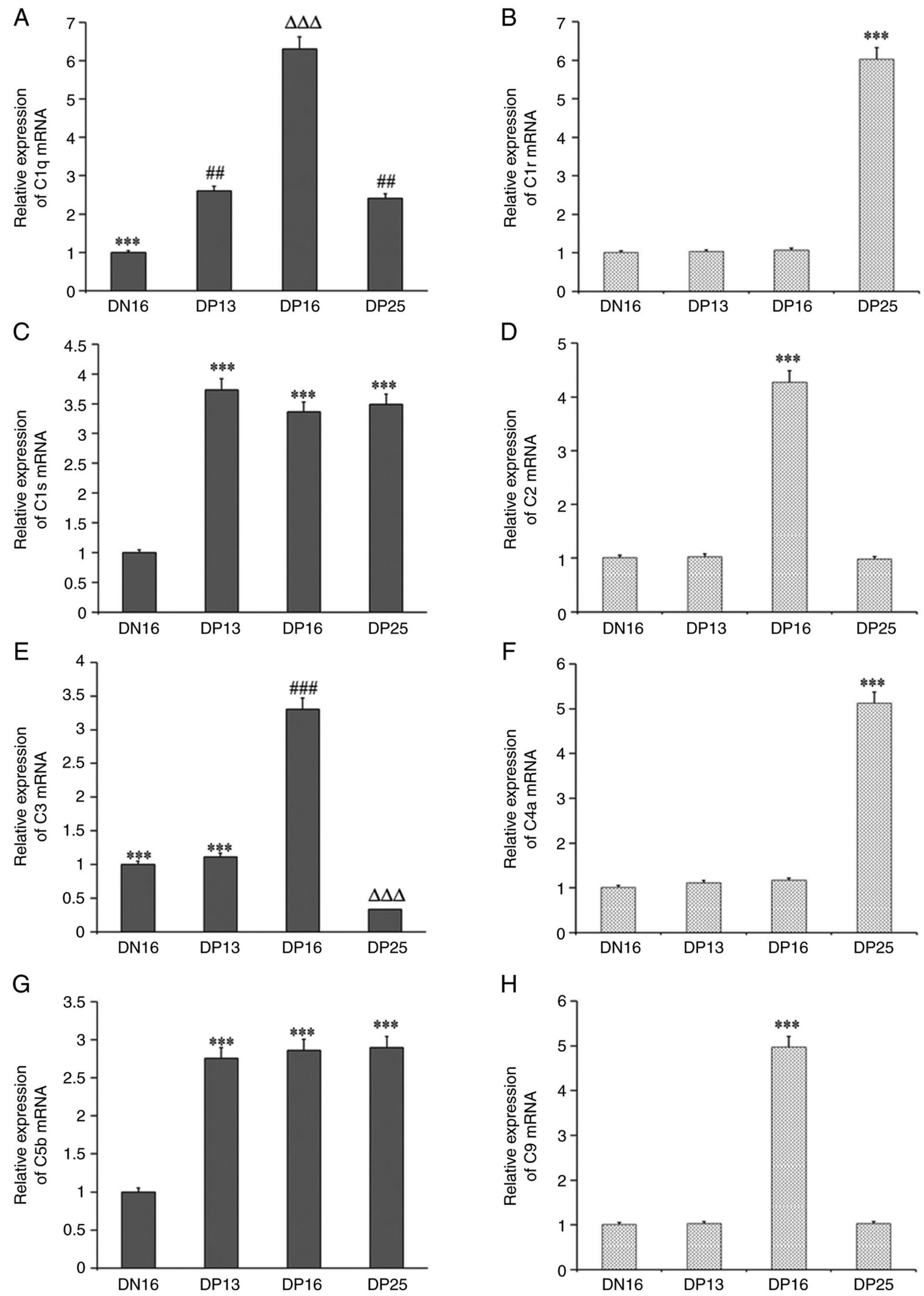

Figure 1. Relative expression values of $C 1 q, C 1 r, C 1 s, C 2, C 3, C 4, C 5$ and $C 9$ mRNAs in the lymph nodes from the non-pregnant and pregnant ewes measured by reverse transcription-quantitative PCR. (A) Relative expression of C1q mRNA. ${ }^{* * *} \mathrm{P}<0.001$. DN16 vs. DP13, DP16 and DP25; ${ }^{\# /} \mathrm{P}<0.01$. DP13 and DP25 vs. DN16 and DP16; ${ }^{\Delta \Delta} \mathrm{P}<0.001$. DP16 vs. DN16, DP13 and DP25. (B) Relative expression of C1r mRNA. ${ }^{* * *} \mathrm{P}<0.001$. DP25 vs. DN16, DP13 and DP16. (C) Relative expression of C1s mRNA. ${ }^{* * *} \mathrm{P}<0.001$. DP13, DP16 and DP25 vs. DN16. (D) Relative expression of C2 mRNA. ${ }^{* * *} \mathrm{P}<0.001$. DP16 vs. DN16, DP13 and DP25. (E) Relative expression of C3 mRNA. ${ }^{* * *} \mathrm{P}<0.001$. DN16 and DP13 vs. DP16 and DP25; ${ }^{\# \# "} \mathrm{P}<0.001$. DP16 vs. DN16, DP13 and DP25; ${ }^{\Delta \Delta} \mathrm{P}<0.001$. DP25 vs. DN16, DP13 and DP16; (F) Relative expression of C4a mRNA. ${ }^{* * *} \mathrm{P}<0.001$. DP25 vs. DN16, DP13 and DP16. (G) Relative expression of C5b mRNA. ${ }^{* * * *} \mathrm{P}<0.001$. DP13, DP16 and DP25 vs. DN16. (H) Relative expression of C9 mRNA. ${ }^{* * *} \mathrm{P}<0.001$. DP16 vs. DN16, DP13 and DP25. DN16, day 16 of the estrous cycle; DP13, day 13 of pregnancy; DP16, day 16 of pregnancy; DP25, day 25 of pregnancy. 
A

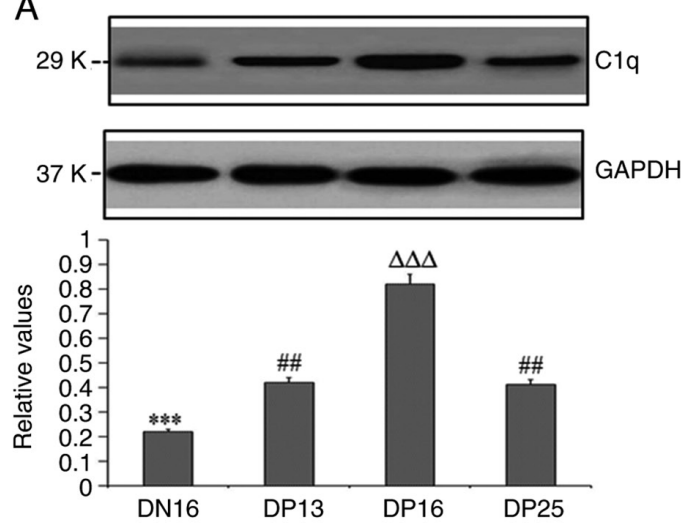

C
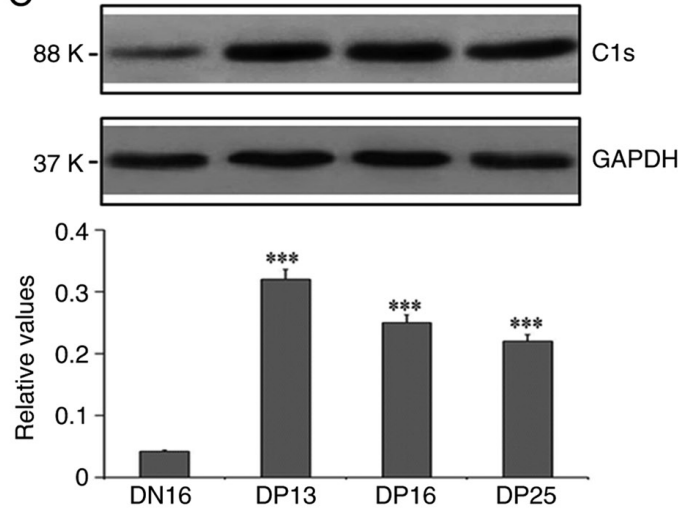

E
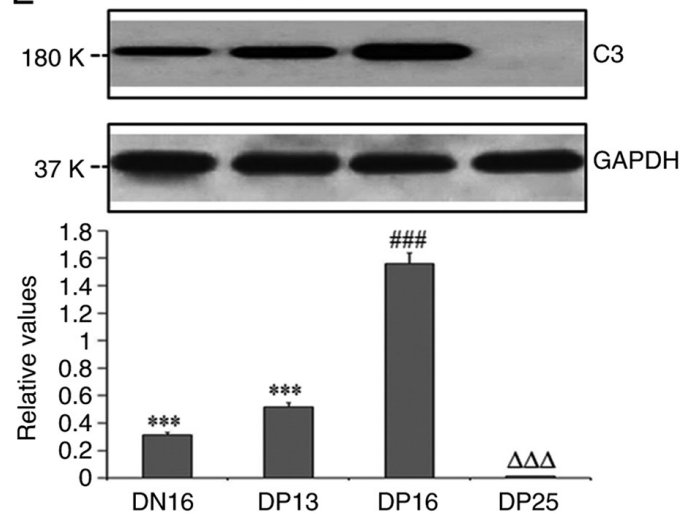

G
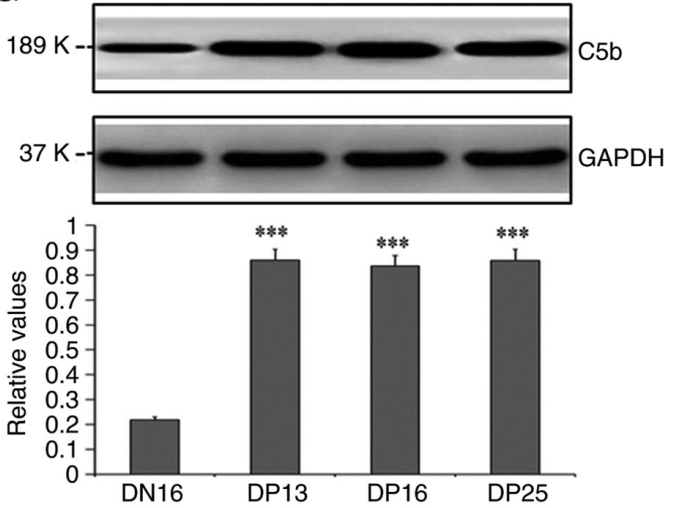

B

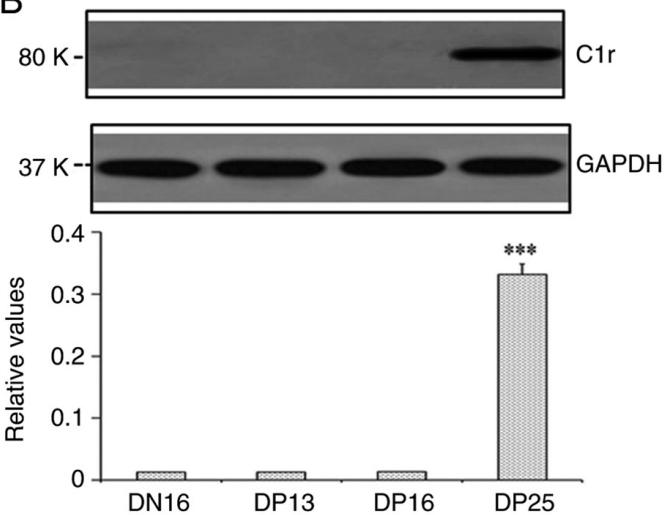

D
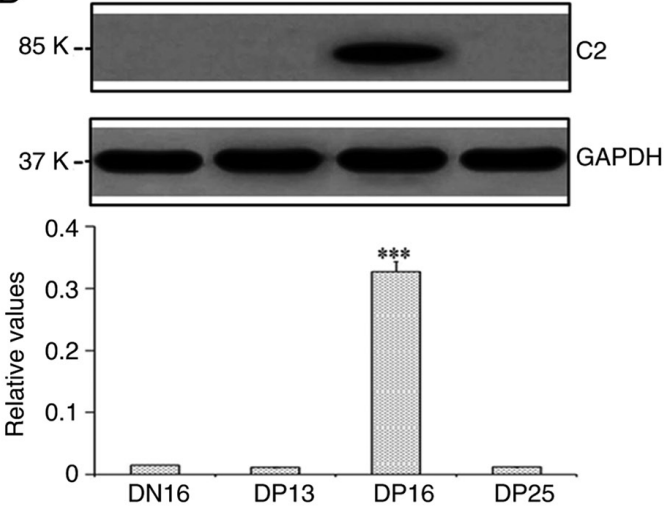

F
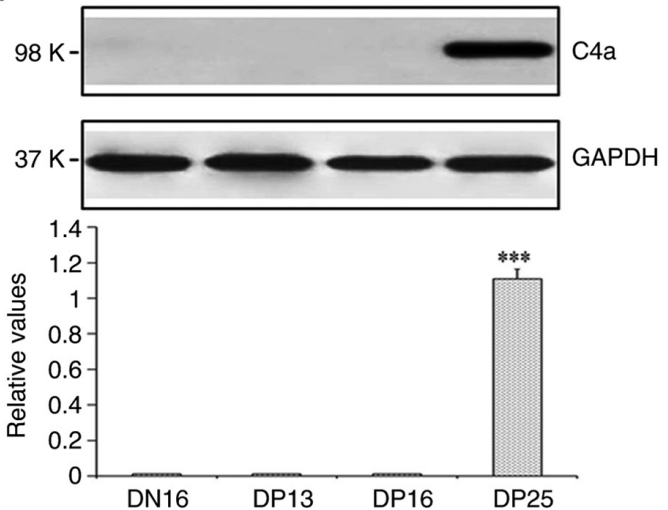

$\mathrm{H}$
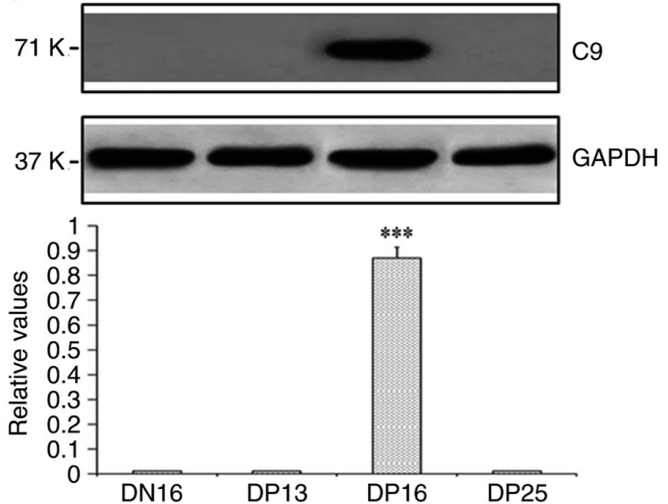

Figure 2. Expression levels of $\mathrm{C} 1 \mathrm{q}, \mathrm{C} 1 \mathrm{r}, \mathrm{C} 1 \mathrm{~s}, \mathrm{C} 2, \mathrm{C} 3, \mathrm{C} 4, \mathrm{C} 5$ and $\mathrm{C} 9$ proteins in the lymph nodes from the non-pregnant and pregnant ewes analyzed using western blotting. (A) Relative expression of Clq protein. ${ }^{* * * *} \mathrm{P}<0.001$. DN16 vs. DP13, DP16 and DP25; ${ }^{* \#} \mathrm{P}<0.01$. DP13 and DP25 vs. DN16 and DP16; ${ }^{\Delta \triangle} \Delta \mathrm{P}<0.001$. DP16 vs. DN16, DP13 and DP25. (B) Relative expression of C1r protein. ${ }^{* * * *} \mathrm{P}<0.001$. DP25 vs. DN16, DP13 and DP16. (C) Relative expression of C1s protein. ${ }^{* * *} \mathrm{P}<0.001$. DP13, DP16 and DP25 vs. DN16. (D) Relative expression of C2 protein. ${ }^{* * *} \mathrm{P}<0.001$. DP16 vs. DN16, DP13 and DP25. (E) Relative expression of C3 protein. ${ }^{* * * *} \mathrm{P}<0.001$. DN16 and DP13 vs. DP16 and DP25; ${ }^{\# \#} \mathrm{P}<0.001$. DP16 vs. DN16, DP13 and DP25; ${ }^{\Delta \Delta} \mathrm{P}<0.001$. DP25 vs. DN16, DP13 and DP16; (F) Relative expression of C4a protein. ${ }^{* * *} \mathrm{P}<0.001$. DP25 vs. DN16, DP13 and DP16. (G) Relative expression of C5b protein. ${ }^{* * *} \mathrm{P}<0.001$. DP13, DP16 and DP25 vs. DN16. (H) Relative expression of C9 protein. ${ }^{* * *} \mathrm{P}<0.001$. DP16 vs. DN16, DP13 and DP25. DN16, day 16 of the estrous cycle; DP13, day 13 of pregnancy; DP16, day 16 of pregnancy; DP25, day 25 of pregnancy. 
A
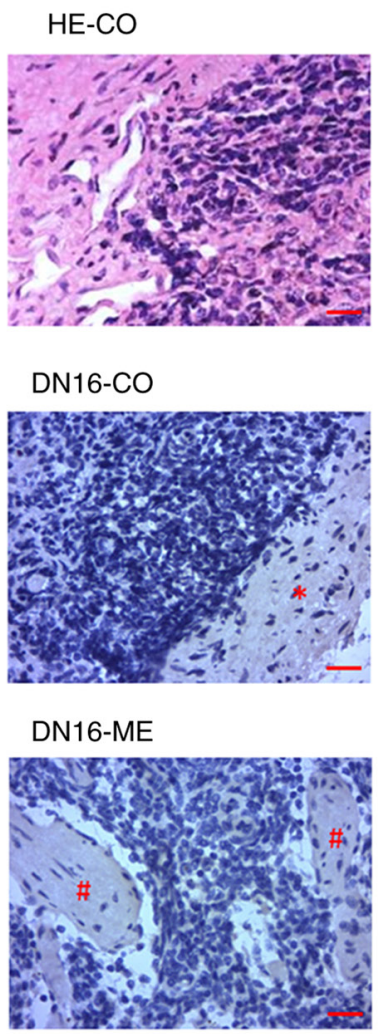

$\mathrm{B}$
HE-ME

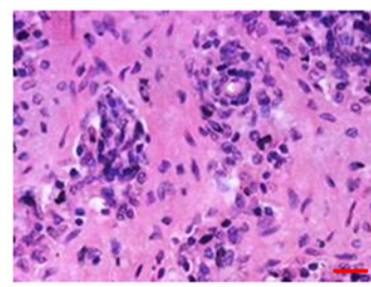

DP13-CO

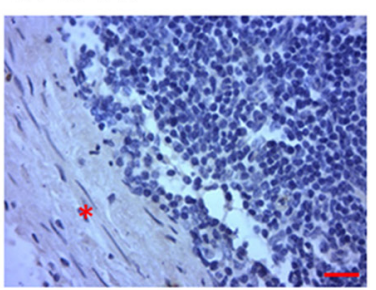

DP13-ME

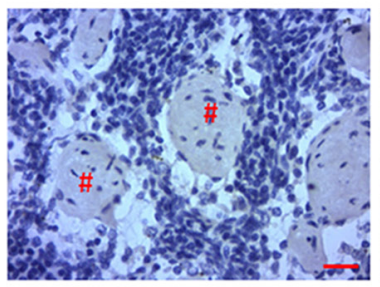

Clt-CO

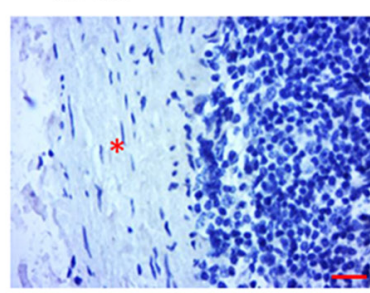

DP16-CO

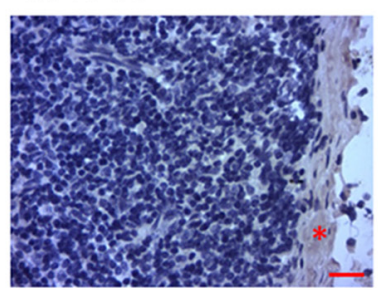

DP16-ME

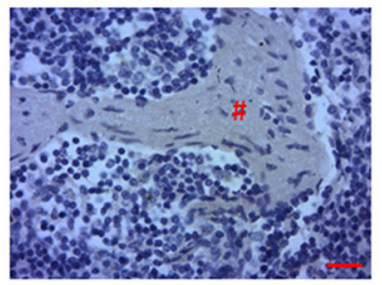

Clt-ME

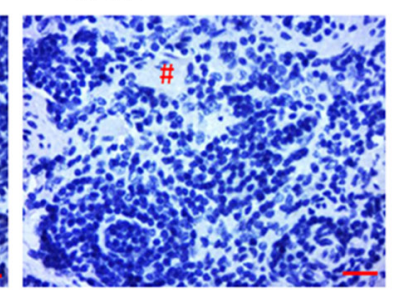

DP25-CO

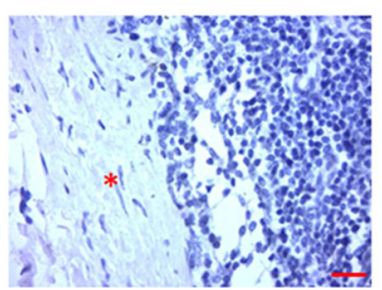

DP25-ME

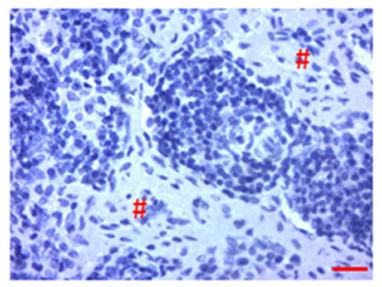

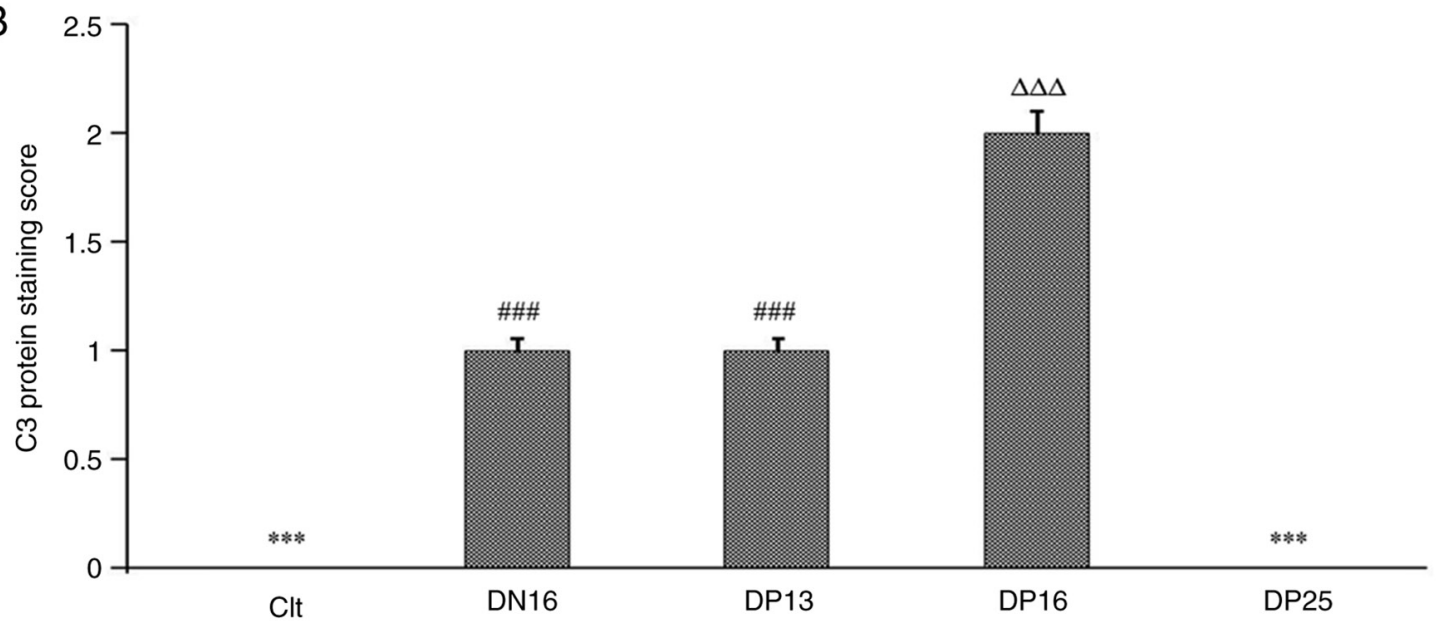

Figure 3. Immunohistochemical localization of C3 protein in the lymph nodes from non-pregnant and pregnant ewes. (A) Immunohistochemical localization of C3 protein. Lymph node is divided into the CO and the ME. Scale bar $=20 \mu \mathrm{m}$. (B) Staining intensities for C3 protein. ${ }^{* * *} \mathrm{P}<0.001$. Clt and DP25 vs. DN16, DP13 and DP16; "\#\# P<0.001. DN16 and DP13 vs. Clt, DP16 and DP25; ${ }^{\Delta \Delta} \mathrm{P}<0.001$. DP16 vs. Clt, DN16, DP13 and DP25. CO, cortex; ME, medulla; HE, hematoxylin and eosin; Clt, control; DN16, day 16 of the estrous cycle; DP13, day 13 of pregnancy; DP16, day 16 of pregnancy; DP25, day 25 of pregnancy.

nodules and medullary cords (Fig. 3). The staining intensities for C3 protein were $0,1+, 1+, 2+$ and 0 for the negative control, the lymph nodes from day 16 of the estrous cycle and lymph nodes from days 13, 16 and 25 of pregnancy, respectively (Fig. 3).

\section{Discussion}

The present study demonstrated that $C l q$ mRNA and protein levels were increased during early pregnancy, and peaked at day 16 of gestation in the maternal lymph node. C1q is a complex glycoprotein with a C-terminal globular head region and an N-terminal collagen-like tail that mediates a variety of immunoregulatory functions (26). C1q participates in feto-maternal tolerance, trophoblast migration and spiral artery remodeling, and the transcription factor PU.1 regulates decidual $\mathrm{C} 1 \mathrm{q}$ expression during early pregnancy in humans (27). Complement Clq can modulate the functions of immune and non-immune cells, and its deficiency and dysregulation result in preeclampsia, missed abortion, miscarriage or spontaneous loss (28). Paternal deficiency of complement component $\mathrm{Clq}$ results in a preeclampsia-like pregnancy, and wild-type female mice exhibit renal dysfunction, fetal growth restriction and reduced placental efficiency during mid- and late gestation (29). Upregulation of anti-Clq antibody levels and thyroid-stimulating hormone levels are associated with to autoimmune thyroid disorders during pregnancy in 
women (30). Mouse Clq is located in various tissues, including lymph nodes (31). Therefore, it is hypothesized that the upregulation of $\mathrm{Clq}$ in the maternal lymph node may be important for embryo implantation during early pregnancy in ewes.

The present study revealed that $\mathrm{C} 1 \mathrm{r}$ was upregulated in the maternal lymph node at day 25 of gestation. As a modular serine protease, $\mathrm{C} 1 \mathrm{r}$ is the autoactivating component of the $\mathrm{C} 1$ complex during activation of the next complement components (32). The complement $\mathrm{C} 1 \mathrm{r}$ subcomponent protein exists in the maternal serum during pregnancy and can be quantified using isotype tagging in humans (33). Amnion tissue explants and amnion-derived epithelial cells synthesize C1r, which indicates that the amnion synthesizes complement C1r (34). $\mathrm{C} 1 \mathrm{q}$ is responsible for the prevention of pregnancy loss, and the immune functions of Clq are mediated by autoactivation of C1r during pregnancy (35). There is an upregulation of the $C 1 R$ gene in peripheral blood polymorphonuclear cells, suggesting that $C 1 R$ is implicated in the early immune response to conceptus presence during the pre-attachment period of pregnancy in heifers (36). Therefore, the upregulation of $\mathrm{C} 1 \mathrm{r}$ in maternal lymph nodes at day 25 of pregnancy may be associated with embryonic development in ewes.

The results of the present study demonstrated that early pregnancy induced the expression of $\mathrm{C} 1 \mathrm{~s}$ in the maternal lymph node, with a peak at day 13 of gestation. The complement component $\mathrm{C} 1$ complex is composed of target-recognition subcomponent $\mathrm{Clq}$ and modular proteases $\mathrm{C} 1 \mathrm{r}$ and $\mathrm{C} 1 \mathrm{~s}$, and $\mathrm{C} 1$ s executes the catalytic function of the $\mathrm{C} 1$ complex to cleave $\mathrm{C} 2$ and $\mathrm{C} 4$ (37). C1s is present in the circulating immune complexes during the first trimester of normal pregnancy, and the $\mathrm{C} 1 \mathrm{~s}$ level decreases during the following weeks of gestation in women (38). $\mathrm{C} 1 \mathrm{~s}$ is detectable in the placenta, and IFN- $\gamma$ stimulates the synthesis of C1s in chorion-derived cells (39). The IFN- $\gamma$ protein is downregulated in bovine peripheral blood mononuclear cells during early pregnancy (40), which may be associated with the decline in $\mathrm{C} 1 \mathrm{~s}$, and the loss of immune response to allograft fetus. Complement $\mathrm{C} 1 \mathrm{~s}$ protein is elevated in maternal plasma of the women with preeclampsia, and is implicated in the remodeling process of the spiral arteries before the manifestation of clinical disease (41). C1s protein is significantly enhanced in the plasma of women carrying Turner syndrome fetuses compared with pregnant women with normal fetuses in the second trimester of pregnancy (42). Therefore, the upregulation of C1s at day 13 of gestation may be associated with initiating implantation, and the downregulation of $\mathrm{C} 1 \mathrm{~s}$ in maternal lymph nodes at day 25 of gestation may be helpful for pregnancy maintenance in ewes.

The results of the current study also revealed that $C 2$ mRNA and protein levels were upregulated in the maternal lymph node at day 16 of gestation. Deficiency of C2 leads to autoimmunity, and $\mathrm{C} 2$ protein participates in both the classical and lectin pathways of the complement cascade, though C2 is not required for activation of the complement system by the classical or lectin pathway (43). C2 does not participate in activation of the complement system on trophoblastic basement membranes through the classical pathway of complement activation, suggesting that $\mathrm{C} 2$ may not be associated with materno-fetal communication during normal human pregnancy (44). C2 deficiency and systemic lupus erythematosus lead to thrombocytopenia and renal abnormalities during the first trimester of pregnancy (45). Interferon stimulates the synthesis of $\mathrm{C} 2$ in human monocytes in vitro (46). IFNT exerts its effects on maternal lymph nodes (6). IFNT (Protein X) and additional proteins are detected between days 14 and 21, and are produced by conceptus trophoblasts in sheep as previously reported (47). It is suggested that the peak of C2 expression at day 16 of pregnancy in the current study may have been associated with the effects of IFNT, which may not be associated with the activation of complement pathways in the lymph nodes of ewes.

In the present study, C3 peaked in maternal lymph nodes at day 16 of gestation, and then decreased at day 25 of gestation. Component C3 acts as a point of convergence of activation pathways to amplify the complement response, and helps to coordinate downstream immune responses (48). A high level of maternal serum C3 in the first trimester is associated with an increased risk of preterm birth, which can be used for the early diagnosis and prognosis of preterm birth in pregnant women (49). C3 is implicated in the development of preeclampsia through bioinformatics-based identification (50). The serum concentration of $\mathrm{C} 3$ is elevated in women with preeclampsia compared with normal pregnant women (51). Human lymph nodes, peripheral blood leucocytes and monocytes can synthesize C3 using an in vitro culture technique (52). It is suggested that the decline of C3 in maternal lymph nodes at day 25 of pregnancy may be required for pregnancy maintenance in sheep.

In the present study, $C 4 a$ mRNA and protein were only expressed in maternal lymph nodes at day 25 of pregnancy. $\mathrm{C} 4 \mathrm{a}$ is an isoform of $\mathrm{C} 4$, and plays key roles in innate immune surveillance, cellular activation and endothelial permeability (53). C4a protein expression is lower in JAR cells under hypoxic conditions compared with normoxic conditions, indicating that preeclampsia is associated with low $\mathrm{C} 4 \mathrm{a}$ and hypoxia (54). Maternal plasma $\mathrm{C} 4 \mathrm{a}$ concentrations are determined by enzyme-linked immunoassay, and there is a lower $\mathrm{C} 4 \mathrm{a}$ level in women with gestational diabetes compared with women with normal glucose tolerance at the time of term delivery (55). A low concentration of maternal plasma $\mathrm{C} 4 \mathrm{a}$ is associated with preeclampsia and small-for-gestational age fetuses during pregnancy (56). Pregnant patients with primary anti-phospholipid syndrome or undifferentiated connective tissue disease have significantly lower levels of serum C4 compared with healthy women in each trimester (57). A low amount of C4 mRNA can be detected in normal human lymph nodes using slot blot hybridization (58). Therefore, it is hypothesized that the upregulation of $\mathrm{C} 4 \mathrm{a}$ in maternal lymph nodes at day 25 of pregnancy may be beneficial for successful pregnancy in ewes.

The results of the present study demonstrated that $C 5 b$ mRNA and protein levels were upregulated in maternal lymph nodes during early gestation compared with day 16 of the estrous cycle. $\mathrm{C} 5$ protein cleaves into $\mathrm{C} 5 \mathrm{a}$ and $\mathrm{C} 5 \mathrm{~b}$, and $\mathrm{C} 5 \mathrm{~b}$ participates in the formation of the membrane attack complex (MAC) associated with C6, C7, C8 and C9 (59). C5 convertase cleaves $\mathrm{C} 5$ to $\mathrm{C} 5 \mathrm{~b}$ to result in $\mathrm{C} 5 \mathrm{~b}-9$ assembly as the MAC pore on the cell surface (60). C5b-9 is detectable in all placentae, and localized in the surface of syncytiotrophoblasts, intervillous fibrin and decidual vessels (61), which contribute to placental formation. There is an increase in C5b-9 staining 
within villous trophoblasts of placentas from normal controls compared with patients with preeclampsia in humans (62). In addition, a lack of C5 is associated with embryonic death in Crry-deficient mice, which suggests that C5 plays a key role in preventing embryonic lethality during early pregnancy (63). Therefore, it is reasonable to hypothesize that the upregulation of C5b in maternal lymph nodes may be helpful for pregnancy maintenance during early pregnancy.

The present study demonstrated that early pregnancy induced the expression of $C 9$ mRNA and protein in maternal lymph nodes at day 16 of gestation. C9 is the final component of the MAC, and the only component of the assembly (64). MACs are involved in pore formation in the plasma membrane of target cells, which is associated with innate and adaptive immune responses (65). Serum C9 levels are significantly higher in healthy pregnant women compared with in non-pregnant women (66). A Japanese woman with C9 deficiency suffered three mid-trimester miscarriages and one early spontaneous miscarriage, suggesting that $\mathrm{C} 9$ deficiency is a potential cause of undiagnosed recurrent miscarriage (67). The deposition of C9 is increased in placentae with preeclampsia compared with normal tissues, which is associated with the chorionic villus immunopathology of preeclampsia in humans (68). C9 deposition increases at the implantation sites in pregnant mice with fetal loss (69). C9 concentration is enhanced in the umbilical cord blood of term infants, which is associated with its role in immunity in prematurity (70). Therefore, it is suggested that the upregulation of $\mathrm{C} 9$ in maternal lymph nodes at day 16 of pregnancy may be associated with placentation, and the downregulation of $\mathrm{C} 9$ at day 25 of pregnancy may be beneficial for pregnancy maintenance in sheep.

Lymph enters the convex system through afferent lymphatic vessels with several branched sinus systems, including subcapsular sinuses, and flows into the blood circulation through efferent lymphatic vessels, including lymph sinuses (71). The immunohistochemistry results of the present study indicated that the immunostaining for $\mathrm{C} 3$ protein was located in the subcapsular sinuses and lymph sinuses. Component $\mathrm{C} 3$ regulates its receptor expression in B cells from the spleen and lymph nodes, which is implicated in innate and adaptive immune responses in mice (72). Therefore, it was suggested that the downregulation of $\mathrm{C} 3$ in the maternal lymph node may be involved in immune tolerance of the maternal lymph node at day 25 of pregnancy in sheep.

In summary, the expression levels of $\mathrm{Clq}, \mathrm{C} 1 \mathrm{~s}$ and $\mathrm{C} 5 \mathrm{~b}$ were increased during early pregnancy, and the expression levels of $\mathrm{C} 1 \mathrm{r}$ and $\mathrm{C} 4 \mathrm{a}$ were increased at day 25 of pregnancy only. There were peaks in the expression levels of C2 and C9 at day 16 of pregnancy. C3 was downregulated at day 25 of pregnancy, and $\mathrm{C} 3$ protein was located in the subcapsular sinuses and lymph sinuses in the maternal lymph nodes. Therefore, the expression profiles of complement components were changed, indicating that complement pathways may be involved in regulating immune responses of the maternal lymph node during early pregnancy in sheep.

\section{Acknowledgements}

Not applicable.

\section{Funding}

This work was supported by the Natural Science Foundation of Hebei Province, China (grant no. C2021402019), and the Science and Technology R\&D Project of Hebei Province, China (grant no. 21326601D).

\section{Availability of data and materials}

The datasets used and/or analyzed during the current study are available from the corresponding author on reasonable request.

\section{Authors' contributions}

LY conceived and designed the experiments. LC and LZ performed the experiments. $\mathrm{PF}$ and $\mathrm{XH}$ analyzed and interpreted the data. LY and LZ wrote the manuscript. LY and LZ confirm the authenticity of all the raw data. All authors read and approved the final manuscript.

\section{Ethics approval and consent to participate}

The study protocol was reviewed and approved by the Hebei University of Engineering Animal Care and Use Committee (approval no. 2019-017), and humane animal care and handling procedures were followed throughout the experiment.

\section{Patient consent for publication}

Not applicable.

\section{Competing interests}

The authors declare that they have no competing interests.

\section{References}

1. Ott TL: Immunological detection of pregnancy: Evidence for systemic immune modulation during early pregnancy in ruminants. Theriogenology 150: 498-503, 2020.

2. Gasteiger G, Ataide M and Kastenmüller W: Lymph node-an organ for T-cell activation and pathogen defense. Immunol Rev 271: 200-220, 2016.

3. Hetherington CM and Humber DP: The effect of pregnancy on lymph node weight in the mouse. J Immunogenet 4: 271-276, 1977.

4. McLean JM, Mosley JG and Gibbs AC: Changes in the thymus, spleen and lymph nodes during pregnancy and lactation in the rat. J Anat 118(Pt 2): 223-229, 1974.

5. Yang L, Zang S, Bai Y, Yao X and Zhang L: Effect of early pregnancy on the expression of progesterone receptor and progesterone-induced blocking factor in ovine lymph node. Theriogenology 93: 78-83, 2017.

6. Yang L, Wang Q, Liu Y, Zhang L, Lv W and Liu B: Expression profiles of interferon-stimulated gene 15 and prostaglandin synthases in the ovine lymph nodes during early pregnancy. Mol Reprod Dev 86: 100-108, 2019.

7. Yang L, Wang P, Mi H, Lv W, Liu B, Du J and Zhang L: Comparison of Th1 and Th2 cytokines production in ovine lymph nodes during early pregnancy. Theriogenology 123: 177-184, 2019.

8. Bai J, Zhang L, Zhao Z, Li N, Wang B and Yang L: Expression of melatonin receptors and CD4 in the ovine thymus, lymph node, spleen and liver during early pregnancy. Immunology 160: 52-63, 2020.

9. Zhang L, Cao L, Yang F, Han X, Wang Y, Cao N and Yang L: Relative abundance of interferon-stimulated genes STAT1, OAS1, CXCL10 and MX1 in ovine lymph nodes during early pregnancy. Anim Reprod Sci 214: 106285, 2020. 
10. Cao N, Cao L, Gao M, Wang H, Zhang L and Yang L: Changes in mRNA and protein levels of gonadotropin releasing hormone and receptor in ovine thymus, lymph node, spleen, and liver during early pregnancy. Domest Anim Endocrinol 76: 106607, 2021.

11. Lubbers $\mathrm{R}$, van Essen MF, van Kooten $\mathrm{C}$ and Trouw LA Production of complement components by cells of the immune system. Clin Exp Immunol 188: 183-194, 2017.

12. Lo MW and Woodruff TM: Complement: Bridging the innate and adaptive immune systems in sterile inflammation. J Leukoc Biol 108: 339-351, 2020.

13. Teirilä L, Heikkinen-Eloranta J, Kotimaa J, Meri S and Lokki AI: Regulation of the complement system and immunological tolerance in pregnancy. Semin Immunol 45: 101337, 2019.

14. Bulla R, Bossi F, Fischetti F, De Seta F and Tedesco F: The complement system at the fetomaternal interface. Chem Immunol Allergy 89: 149-157, 2005.

15. Girardi G and Salmon JB: The role of complement in pregnancy and fetal loss. Autoimmunity 36: 19-26, 2003.

16. Feng P, Yang G, Zhang W, Zhang L, Wu J and Yang L: Early pregnancy regulates expression of complement components in ovine liver. Anim Sci J 92: e13660, 2021.

17. Zhang L, Zhang Q, Wang H, Feng P, Yang G and Yang L: Effects of early pregnancy on the complement system in the ovine thymus. Vet Res Commun: Sep 24, 2021 (Epub ahead of print).

18. Forde $\mathrm{N}$ and Lonergan P: Interferon-tau and fertility in ruminants. Reproduction 154: F33-F43, 2017.

19. Hansen TR, Sinedino LDP and Spencer TE: Paracrine and endocrine actions of interferon tau (IFNT). Reproduction 154 F45-F59, 2017.

20. Yang L, Liu B, Yan X, Zhang L, Gao F and Liu Z: Expression of ISG15 in bone marrow during early pregnancy in ewes. Kafkas Univ Vet Fak Derg 23: 767-772, 2017.

21. Zhang L, Xue J, Wang Q, Lv W, Mi H, Liu Y and Yang L: Changes in expression of ISG15, progesterone receptor and progesterone-induced blocking factor in ovine thymus during early pregnancy. Theriogenology 121: 153-159, 2018.

22. Yang L, Liu Y, Lv W, Wang P, Wang B, Xue J and Zhang L: Expression of interferon-stimulated gene $15-\mathrm{kDa}$ protein cyclooxygenase (COX) 1, COX-2, aldo-keto reductase family 1 , member B1, and prostaglandin E synthase in the spleen during early pregnancy in sheep. Anim Sci J 89: 1540-1548. 2018 .

23. Wang Y, Han X, Zhang L, Cao N, Cao L and Yang L: Early pregnancy induces expression of STAT1, OAS1 and CXCL10 in ovine spleen. Animals (Basel) 9: E882, 2019.

24. Livak KJ and Schmittgen TD: Analysis of relative gene expression data using real-time quantitative PCR and the 2(-Delta Delta C(T)) method. Methods 25: 402-408, 2001.

25. Kandil D, Leiman G, Allegretta M, Trotman W, Pantanowitz L, Goulart R and Evans M: Glypican-3 immunocytochemistry in liver fine-needle aspirates: A novel stain to assist in the differentiation of benign and malignant liver lesions. Cancer 111 316-322, 2007

26. Thielens NM, Tedesco F, Bohlson SS, Gaboriaud C and Tenner AJ. C1q: A fresh look upon an old molecule. Mol Immunol 89: 73-83, 2017

27. Madhukaran SP, Kishore U, Jamil K, Teo BH, Choolani M and $\mathrm{Lu}$ J: Transcriptional factor PU.1 regulates decidual C1q expression in early pregnancy in human. Front Immunol 6: 53, 2015.

28. Kouser L, Madhukaran SP, Shastri A, Saraon A, Ferluga J, Al-Mozaini $\mathrm{M}$ and Kishore U: Emerging and novel functions of complement protein C1q. Front Immunol 6: 317, 2015.

29. Sutton EF, Gemmel M, Brands J, Gallaher MJ and Powers RW Paternal deficiency of complement component Clq leads to a preeclampsia-like pregnancy in wild-type female mice and vascular adaptations postpartum. Am J Physiol Regul Integr Comp Physiol 318: R1047-R1057, 2020.

30. Vitkova H, Jiskra J, Springer D, Limanova Z, Telicka Z, Bartakova J, Trendelenburg $M$ and Potlukova E: Anti-Clc autoantibodies are linked to autoimmune thyroid disorders in pregnant women. Clin Exp Immunol 186: 10-17, 2016.

31. McManus LM and Nakane PK: Mouse clq: Light and electron microscopic immunohistochemical localization. J Immunol 126 : $1421-1427,1981$

32. Kardos J, Harmat V, Palló A, Barabás O, Szilágyi K, Gráf L, Náray-Szabó G, Goto Y, Závodszky P and Gál P: Revisiting the mechanism of the autoactivation of the complement protease $\mathrm{C} 1 \mathrm{r}$ in the $\mathrm{C} 1$ complex: structure of the active catalytic region of $\mathrm{C} 1 \mathrm{r}$. Mol Immunol 45: 1752-1760, 2008.
33. Scholl PF, Cole RN, Ruczinski I, Gucek M, Diez R, Rennie A, Nathasingh C, Schulze K, Christian P, Yager JD, et al: Maternal serum proteome changes between the first and third trimester of pregnancy in rural southern Nepal. Placenta 33: 424-432, 2012.

34. Katz Y, Gur S, Aladjem M and Strunk RC: Synthesis of complement proteins in amnion. J Clin Endocrinol Metab 80: 2027-2032, 1995.

35. Oberkersch R, Attorresi AI and Calabrese GC: Low-molecular-weight heparin inhibition in classical complement activation pathway during pregnancy. Thromb Res 125: e240-5, 2010

36. Rocha CC, da Silva Andrade SC, de Melo GD, Motta IG, Coutinho LL, Gonella-Diaza AM, Binelli M and Pugliesi G: Early pregnancy-induced transcripts in peripheral blood immune cells in Bos indicus heifers. Sci Rep 10: 13733, 2020

37. Gál P, Ambrus G and Závodszky P: C1s, the protease messenger of $\mathrm{C} 1$. Structure, function and physiological significance. Immunobiology 205: 383-394, 2002.

38. Schena FP, Manno C, Selvaggi L, Loverro G, Bettocchi S and Bonomo L: Behaviour of immune complexes and the complement system in normal pregnancy and pre-eclampsia. J Clin Lab Immunol 7: 21-26, 1982

39. Goldberg M, Luknar-Gabor N, Keidar R and Katz Y: Synthesis of complement proteins in the human chorion is differentially regulated by cytokines. Mol Immunol 44: 1737-1742, 2007.

40. Yang L, Wang Y, Li S, Zhu M, He K, Yao X and Zhang L: Differential expression of interferon-gamma, IL-4 and IL-10 in peripheral blood mononuclear cells during early pregnancy of the bovine. Reprod Biol 18: 312-315, 2018.

41. Kim SM, Cho BK, Kang MJ, Norwitz ER, Lee SM, Lee J, Park CW, Kim BJ, Jun JK, Park JS, et al: Expression changes of proteins associated with the development of preeclampsia in maternal plasma: A case-control study. Proteomics 16: $1581-1589,2016$

42. Kolialexi A, Anagnostopoulos AK, Papantoniou N, Vougas K, Antsaklis A, Fountoulakis M, Mavrou A and Tsangaris GT: Potential biomarkers for Turner in maternal plasma: possibility for noninvasive prenatal diagnosis. J Proteome Res 9: 5164-5170, 2010.

43. Miller EC and Atkinson JP: Overcoming C2 deficiency. Clin Immunol 144: 269-271, 2012.

44. Faulk WP, Jarret R, Keane M, Johnson PM and Boackle RJ: Immunological studies of human placentae: Complement components in immature and mature chorionic villi. Clin Exp Immunol 40: 299-305, 1980 .

45. Dixit R, Krieg AM and Atkinson JP: Thrombotic thrombocytopenic purpura developing during pregnancy in a C2-deficient patient with a history of systemic lupus erythematosus. Arthritis Rheum 28: 341-344, 1985 .

46. Lappin DF, Birnie GD and Whaley K: Modulation by interferons of the expression of monocyte complement genes. Biochem J 268: 387-392, 1990.

47. Godkin JD, Bazer FW, Moffatt J, Sessions F and Roberts RM: Purification and properties of a major, low molecular weight protein released by the trophoblast of sheep blastocysts at day 13-21. J Reprod Fertil 65: 141-150, 1982.

48. Ricklin D, Reis ES, Mastellos DC, Gros P and Lambris JD: Complement component C3-The 'Swiss Army Knife' of innate immunity and host defense. Immunol Rev 274: 33-58, 2016

49. Huang S, Tian J, Liu C, Long Y, Cao D, Wei L, Zhu X, Tang R, Liu W,Zeng D, et al: Elevated C-reactive protein and complement $\mathrm{C} 3$ levels are associated with preterm birth: A nested case-control study in Chinese women. BMC Pregnancy Childbirth 20: 131, 2020.

50. Jiang R, Wang $\mathrm{T}$, Zhou $\mathrm{F}$, Yao $\mathrm{Y}, \mathrm{He} \mathrm{J}$ and $\mathrm{Xu} \mathrm{D}$ : Bioinformatics-based identification of miRNA-, lncRNA-, and mRNA-associated ceRNA networks and potential biomarkers for preeclampsia. Medicine (Baltimore) 99: e22985, 2020.

51. Kestlerová A, Feyereisl J, Frisová V, Měchurová A, Š̉ůla K, Zima T, Běláček J and Madar J: Immunological and biochemical markers in preeclampsia. J Reprod Immunol 96: 90-94, 2012.

52. Lai A Fat RF and van Furth R: In vitro synthesis of some complement components (C1q, C3 and $\mathrm{C} 4$ ) by lymphoid tissues and circulating leucocytes in man. Immunology 28: 359-368, 1975.

53. Wang H, Ricklin D and Lambris JD: Complement-activation fragment $\mathrm{C} 4 \mathrm{a}$ mediates effector functions by binding as untethered agonist to protease-activated receptors 1 and 4 . Proc Natl Acad Sci USA 114: 10948-10953, 2017. 
54. Zhang H, Zhang Y, Yang F, Li L, Liu S, Xu Z, Wang J and Sun S: Complement component C4A and apolipoprotein A-I in plasmas as biomarkers of the severe, early-onset preeclampsia. Mol Biosyst 7: 2470-2479, 2011.

55. Lappas M: Lower circulating levels of complement split proteins $\mathrm{C} 3 \mathrm{a}$ and $\mathrm{C} 4 \mathrm{a}$ in maternal plasma of women with gestational diabetes mellitus. Diabet Med 28: 906-911, 2011.

56. Soto E, Romero R, Richani K, Espinoza J, Chaiworapongsa T, Nien JK, Edwin SS, Kim YM, Hong JS, Goncalves LF, et al: Preeclampsia and pregnancies with small-for-gestational age neonates have different profiles of complement split products. J Matern Fetal Neonatal Med 23: 646-657, 2010.

57. Reggia R, Ziglioli T, Andreoli L, Bellisai F, Iuliano A, Gerosa M, Ramoni V, Tani C, Brucato A, Galeazzi M, et al: Primary anti-phospholipid syndrome: any role for serum complement levels in predicting pregnancy complications? Rheumatology (Oxford) 51: 2186-2190, 2012.

58. Feucht HE, Zwirner J, Bevec D, Lang M, Felber E, Riethmüller G and Weiss EH: Biosynthesis of complement C4 messenger RNA in normal human kidney. Nephron 53: 338-342, 1989.

59. Laursen NS, Magnani F, Gottfredsen RH, Petersen SV and Andersen GR: Structure, function and control of complement C5 and its proteolytic fragments. Curr Mol Med 12: 1083-1097, 2012.

60. Regal JF, Burwick RM and Fleming SD: The complement system and preeclampsia. Curr Hypertens Rep 19: 87, 2017.

61. Chighizola CB, Lonati PA, Trespidi L, Meroni PL and Tedesco F The complement system in the pathophysiology of pregnancy and in pystemic autoimmune rheumatic diseases during pregnancy. Front Immunol 11: 2084, 2020

62. Matrai CE, Rand JH and Baergen RN: Absence of distinct immunohistochemical distribution of annexin A5, C3b, C4d, and C5b-9 in placentas from patients with antiphospholipid antibodies, preeclampsia, and systemic lupus erythematosus. Pediatr Dev Pathol 22: 431-439, 2019.

63. Mao D, Wu X, Deppong C, Friend LD, Dolecki G, Nelson DM and Molina H: Negligible role of antibodies and C5 in pregnancy loss associated exclusively with $\mathrm{C} 3$-dependent mechanisms through complement alternative pathway. Immunity 19: 813-822, 2003.

64. Spicer BA, Law RHP, Caradoc-Davies TT, Ekkel SM, Bayly-Jones C, Pang SS, Conroy PJ, Ramm G, Radjainia M, Venugopal $\mathrm{H}$, et al: The first transmembrane region of complement component- 9 acts as a brake on its self-assembly. Nat Commun 9: 3266, 2018
65. Xie CB, Jane-Wit D and Pober JS: Complement membrane attack complex: New roles, mechanisms of action, and therapeutic targets. Am J Pathol 190: 1138-1150, 2020.

66. Derzsy Z, Prohászka Z, Rigó J Jr, Füst G and Molvarec A: Activation of the complement system in normal pregnancy and preeclampsia. Mol Immunol 47: 1500-1506, 2010.

67. Watanabe N, Suzuki T, Kitano E, Kitamura H, Hatanaka M and Sago H: Successful pregnancy in a patient suffering from recurrent mid-trimester miscarriage with $\mathrm{C} 9$ deficiency after receiving cervical cerclage followed by clindamycin and progesterone: A case report. J Obstet Gynaecol Res 38: 562-566, 2012.

68. Sinha D, Wells M and Faulk WP: Immunological studies of human placentae: Complement components in pre-eclamptic chorionic villi. Clin Exp Immunol 56: 175-184, 1984.

69. Agostinis C, Biffi S, Garrovo C, Durigutto P, Lorenzon A, Bek A, Bulla R, Grossi C, Borghi MO, Meroni P and Tedesco F: In vivo distribution of $\beta 2$ glycoprotein I under various pathophysiologic conditions. Blood 118: 4231-4238, 2011.

70. Gródecka-Szwajkiewicz D, Ulańczyk Z, Zagrodnik E, Łuczkowska K, Rogińska D, Kawa MP, Stecewicz I, Safranow K, Ustianowski P, Szymański S and Machaliński B: Comparative analysis of global gene expression and complement components levels in umbilical cord blood from preterm and term neonates: Implications for significant downregulation of immune response pathways related to prematurity. Int J Med Sci 17: 1840-1853, 2020.

71. Jalkanen S and Salmi M: Lymphatic endothelial cells of the lymph node. Nat Rev Immunol 20: 566-578, 2020.

72. Jacobson AC, Roundy KM, Weis JJ and Weis JH: Regulation of murine splenic B cell CR3 expression by complement component 3. J Immunol 183: 3963-3970, 2009.

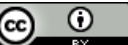

This work is licensed under a Creative Commons Attribution 4.0 International (CC BY 4.0) License. 